\title{
STUDI PEMBUATAN TEPUNG TERIPANG DARI BAHAN BAKU TERIPANG PASIR (HOLOTHURIA SCABRA) DENGAN PERLAKUAN PERBEDAAN KONSENTRASI GARAM DAN PERBEDAAN LAMA PEREBUSAN
}

\section{(Study of Sea Cucumber Flour Production from Sea Cucumber (Holothuria scabra) with Treatment of Differences of Salt Concentration and Old Boiling Differences)}

\author{
Rindam Latief $^{1 *}$, Amran Laga ${ }^{1)}$, dan Syamsul Alang ${ }^{1)}$ \\ ${ }^{1 *}$ Program Studi Ilmu dan Teknologi Pangan Departemen Teknologi Pertanian Universitas Hasanuddin \\ Makassar, Indonesia \\ *)email Penulis Korespondensi: rindamias04@yahoo.com
}

\begin{abstract}
ABSTRAK
Teripang memiliki prospek menjadi salah satu sumber makanan paling bergizi karena memiliki kandungan nutrisi lengkap, termasuk karbohidrat, beberapa jenis asam lemak dan asam amino, beberapa komponen vitamin, sterol dan beberapa jenis mineral. Kandungan nutrisi yang tinggi membuat teripang berpotensi sebagai sumber makanan faktor pertumbuhan tinggi. Selain itu, kandungan yang dimiliki teripang juga diyakini berfungsi sebagai antioksidan, antibakteri, antifungi, dan antikoagulan. Di Indonesia, teripang masih belum banyak digunakan sebagai makanan. Penelitian ini mempelajari bagaimana pengaruh garam dan perebusan terhadap kualitas isi dan penerimaan fisik teripang oleh masyarakat. Produksi teripang dengan metode perebusan dan penggaraman didasarkan pada kebiasaan orang-orang yang merebus atau merebus mentimun laut pada saat setelah teripang ditangkap. Konsentrasi garam yang diberikan dalam penelitian ini adalah 10\%, 15\% dan 20\%. Sedangkan perlakuan suhu dilakukan dengan merebus teripang selama 10 menit, 20 menit dan 30 menit dengan suhu $70 \mathrm{oC}$. Hasil yang diperoleh dari penelitian ini menunjukkan bahwa kandungan gizi teripang dalam kelompok mendidih memiliki nilai rata-rata kadar air sebesar 18,20\%, kadar abu $19,61 \%$, protein $51,17 \%$, lemak $3,76 \%$ dan karbohidrat $7,27 \%$. Sedangkan kandungan gizi teripang dalam kelompok pengasinan memiliki nilai rata-rata kadar air $14,01 \%$, abu 14,49\%, lemak 57,24\%, lemak 4,09\% dan karbohidrat 10,17\%. Hasil analisis varians menunjukkan bahwa teripang yang dihasilkan dari kelompok mendidih dan kelompok penggaraman tidak berpengaruh nyata terhadap kadar hara dan parameter organoleptik teripang. Kesimpulannya diperoleh bahwa pembuatan teripang baik dengan perlakuan merebus atau pengasinan diklasifikasikan sebagai memiliki kandungan gizi yang cukup tinggi. Jadi sangat potensial untuk dikembangkan lebih luas pada produk makanan kaya gizi
\end{abstract}

Kata Kunci : teripang, salting, mendidih, tepung teripang.

\section{ABSTRACT}

Sea cucumbers have the prospect of being one of the most nutritious food sources because it has a complete nutritional content, including carbohydrates, some types of fatty acids and amino acids, some components of vitamins, sterols and some types of minerals. High nutritional content makes sea cucumber has potential as a food source of high grow factor. In addition, the content owned by sea cucumbers are also believed to function as antioxidants, antibacteria, antifungi, and anticoagulants. In Indonesia, sea cucumbers are still not widely used as food. This research studied how the effect of salt and boiling on the quality of content and physical acceptance of sea cucumber flour by the community. The production of sea cucumber by boiling and salting method is based on the habit of the people who boil or salt the sea cucumber at the time after the sea cucumber is captured. The salt 
concentration given in this study was $10 \%, 15 \%$ and $20 \%$. While the temperatur treatment done by boiling sea cucumber for 10 minutes, 20 minutes and 30 minutes with a temperature of $70 o C$. The results obtained from this study showed that the nutrient content of sea cucumbers in boiling group has an average value of water content of $18.20 \%$, ash content $19.61 \%$, protein $51.17 \%$, fat $3.76 \%$ and carbohydrates $7.27 \%$. While the nutritional content of sea cucumber in salting group has an average value of water content $14.01 \%$, ash $14.49 \%$, $57.24 \%$, fat $4.09 \%$ and carbohydrates $10.17 \%$. The result of variance analysis showed that the sea cucumber produced from the boiling group and salting group did not significantly affect the nutrient content and the organoleptic parameters of sea cucumber. The conclusion obtained that the manufacture of sea cucumber either with the treatment of boiling or salting classified as having a fairly high nutritional content. So it is very potential to be developed more broadly on nutrient-rich food products.

Keywords : Sea cucumbers, Salting, Boiling, sea cucumberd flour.

\section{PENDAHULUAN}

Indonesia merupakan salah satu negara penghasil teripang (sea cucumber) terbesar di dunia. Saat ini perdagangan teripang telah meluas, terutama di Hongkong dan Singapura, yang merupakan dua negara pusat perdagangan ekspor teripang dunia. Teripang kering telah diolah dan diperdagangkan di USA, Kanada, Eropa, Taiwan, Republik Korea, China, Australia, Malaysia, Thailand dan beberapa negara lain.

Ketersediaan teripang yang cukup melimpah di Indonesia menjadi keharusan bahwa penelitian mengenai teripang

Sebagai pangan fungsional di Indonesia masih perlu dikembangkan bila dibandingkan dengan penelitian mancanegara. Penelitian khasiat teripang di Indonesia masih cenderung menjadikan teripang sebagai penambah vitalitas (dan antibakteri.

Teripang menjadi salah satu sumber pangan yang penuh nutrisi karena memiliki kandungan gizi yang lengkap, antara lain karbohidrat, asam lemak, jenis asam amino esensial, komponen vitamin, sterol. dan beberapa zat-zat mineral.

Kandungan protein teripang yang tinggi dapat meningkatkan regenerasi selsel mati akibat luka sehingga mampu menyembuhkan luka, memperkuat sistem daya tahan tubuh serta menghasilkan hormon dan enzim untuk melancarkan metabolisme.

Kandungan asam lemak yang terdapat pada teripang pada umumnya seperti asam miristat, palmitat, almitoleat, stearat, oleat, linoleat, arakhsidat, eicosapentaenat, behenat, erusat, dan docosahexaenat.

Pengembangan produk teripang saat ini lebih cenderung mengarah pada bidang farmasi yang berfungsi sebagai sumber bahan obat dan nutraceutical. Dalam bentuk pangan teripang biasanya dipasarkan langsung dalam bentuk kering. Produk olahan teripang diantaranya masih berupa teripang kering (beche-de-mer), gonad kering (konoko), usus kering (konowata) dan kerupuk.

Penelitian ini difokuskan untuk menjawab bagaimana pengaruh pemberian garam dan perebusan terhadap mutu tepung teripang serta bagaimana tingkat penerimaan masyarakat terhadap produk yang dihasilkan melalui parameter uji organoleptik.

Tujuan dilakukannya penelitian ini adalah untuk mempelajari cara mengolah teripang yang kaya akan gizi dan metabolit sekunder menjadi bahan baku pangan.

Kegunaan penelitian ini diharapkan dapat memberikan kontribusi bagi ilmu pengetahuan dan khususnya dalam bidang pengembangan pangan kaya nutrisi. Penelitian ini juga diharapkan menjadi informasi kepada masyarakat umum dan 
para pelaku industri mengenai cara pengolahan teripang sebagai pangan.

\section{METODOLOGI PENELITIAN}

\subsection{Alat}

Alat yang digunakan dalam penelitian ini adalah gelas ukur, grinder, sendok, blower, pisau, talenan, wadah/baskom, ayakan 100 mesh, timbangan analitik, oven, tanur, hotplate cawan porselen dan alat-alat untuk uji organoleptik.

\subsection{Bahan}

Bahan yang digunakan yaitu teripang pasir, $\mathrm{NaCl}$, Akuades, K2CrO4, AgNO3, air, dan aluminium foil.

\subsection{Prosedur Penelitian}

\subsubsection{Format Penulisan}

Teripang dibelah dan dibuang isi perutya. Kemudian dicuci dengan air hingga teripang bebas dari isi perut. Sampel ditimbang dengan berat masing-masing 500 gr dan diberi perlakuan sesuai dengan perlakuan masing - masing (kontrol, perebusan dalam suhu $70{ }^{\circ} \mathrm{C}$ dan penggaraman). Semua kemudian sampel dikeringkan menggunakan oven vacum selama 24 jam menggunakan suhu $60{ }^{\circ} \mathrm{C}$. Sampel digrinder hingga menjadi tepung. Tahapan terakhir dilakukan.

\subsubsection{Desain Penelitian}

Perlakuan yang diaplikasikan dalam penelitian pembuatan tepung teripang ini adalah perlakuan perebusan dan perlakuan penggaraman dengan pembagian sebagai berikut :

A $0=$ Kontrol (daging teripang segar)

A1 $=$ Perebusan selama 10 menit

A2 $=$ Perebusan selama 20 menit

A3 = Perebusan selama 30 menit

$\mathrm{B} 1=$ Penggaraman konsentrasi $10 \%$

B2 $=$ Penggaraman konsentrasi $15 \%$

B3 = Penggaraman konsentrasi $20 \%$

\subsubsection{Parameter Pengamatan}

Pada penelitian ini dilakukan analisis berupa analisis kimia dan organoleptik. Parameter pengamatan yang dilakukan yaitu: Analisis Kimia (Kadar air, Kadar Abu, Kadar Protein, Kadar lemak, Analisis Karbohidrat by Difference, Kadar $\mathrm{NaCl}$ dan Uji Organoleptik Skala Hedonik.

\subsubsection{Pengolahan Data}

Data yang diperoleh dari penelitian ini diolah dengan menggunakan metode Rancangan Acak Kelompok yang kemudian dilanjutkan dengan Uji Duncan dan Uji TTest. Uji Duncan digunakan untuk melihat perbedaan nilai tengah dari kedua kelompok perlakuan pada setiap parameter uji yang berbeda nyata. Sedangkan uji TTest digunakan untuk melihat perbandingan nilai tengah dari kedua kelompok perlakuan dari semua parameter uji.

\section{HASIL DAN PEMBAHASAN}

\subsection{Kadar Air}

Hasil analisa sidik ragam menunjukkan bahwa $\mathrm{F}$ hitung $>0,05$. Berdasarkan data ini dapat disimpulkan bahwa baik perlakuan penggaraman maupun perebusan tidak memiliki pengaruh nyata terhadap kandungan kadar air tepung teripang yang dihasilkan, sehingga tidak dilakukan uji lanjut.

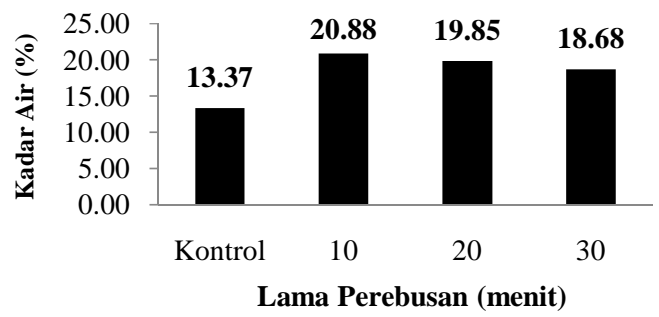

Gambar 1 Hubungan Lama Perebusan dengan Jumlah Kadar Air Tepung Teripang Perlakuan Perebusan

Pada kondisi kontrol menuju perebusan selama 10 menit terjadi peningkatan kadar air yang signifikan. Pada perebusan selama 10 menit menuju menit ke 20 dan 30 kadar air kembali mengalami penurunan. Hal ini disebabkan karena pada perebusan 10 menit daging teripang yang memiliki banyak 
jaringan cenderung masih kuat menyimpan air karena kondisi jaringan yang belum mengalami kerusakan. Semakin lama pemanasan akan membuat jaringan teripang terurai.

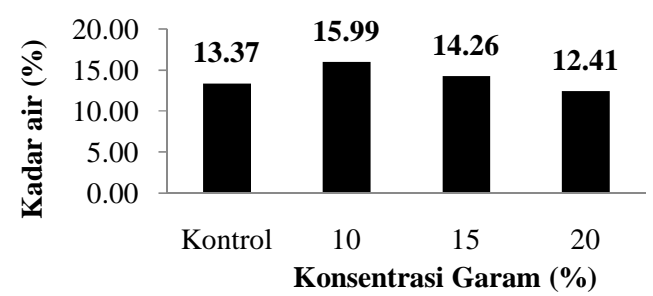

Gambar 2 Hubungan Konsentrasi Garam dengan Tingkat Kadar Air Tepung Teripang Perlakuan Penggaraman

Penurunan kadar air dengan semakin tingginya konsentrasi garam yang diberikan disebabkan oleh selama proses penggaraman berlangsung terjadi penetrasi garam ke dalam daging teripang yang mengakibatkan keluarnya cairan dari jaringan daging karena adanya perbedaan konsentrasi. (Rochima, 2005) mengatakan bahwa penurunan kadar air dalam bahan pangan dapat terjadi karena adanya penambahan garam sehingga menyebabkan keseimbangan air dalam bahan pangan terganggu. Garam akan menarik air dari dalam bahan lalu masuk ke dalam jaringan. Akibatnya, kadar air bahan menurun.

\subsection{Kadar Abu}

Hasil analisa sidik ragam menujukkan hasil bahwa $F$ hitung $>0,05$ yang menyatakan sampel dengan kelompok perebusan dan kelompok penggaraman tidak memberikan pengaruh nyata terhadap kandungan kadar abu tepung teripang yang dihasilkan, sehingga tidak dilakukan uji lanjut.

Gambar 3 Hubungan Lama Perebusan dengan Jumlah Kadar Abu Tepung Teripang Perlakuan Perebusan.

Gambar 3 menujukan sampel cenderung mengalami peningkatan secara bertahap. Kondisi tersebut diakibatkan oleh adanya pengaruh pemanasan yang dilakukan. Panas yang diterima oleh bahan yang semakin lama menyebabkan kandungan yang rentan terhadap suhu panas mengalami kerusakan dan menguap. Sedangkan mineral pada perlakuan panas yang relatif rendah pada saat perebusan tidak mendapatkan pengaruh secara signifikan. Sejalan dengan pernyataan. (Apriantono, 2002), bahwa pada umumnya mineral tidak terpengaruh secara signifikan dengan perlakuan kimia

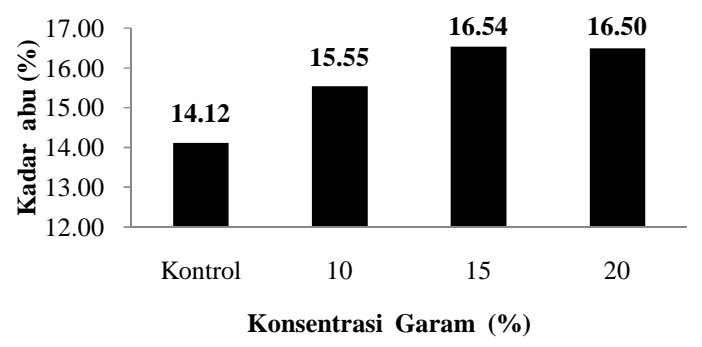

dan fisik selama pengolahan.

Gambar 4 Hubungan Konsentrasi Garam dengan

Tingkat Kadar Abu Tepung Teripang Perlakuan Penggaraman

Data yang ditunjukkan pada Gambar 4. menunjukkan bahwa terjadi peningkatan kadar abu dengan semakin tingginya konsentrasi garam yang diberikan. Peningkatan kadar abu sangat erat kaitannya dengan faktor penambahan garam sebagai senyawa anorganik. Semakin tinggi kadar garam maka semakin tinggi pula kadar abu tepung teripang. Menurut (Harmayani, Utami., \& Khairina, 2000) dalam penelitiannya mengenai penggaraman ikan, menyatakan bahwa pemberian garam menyebabkan pertambahan jumlah mineral (terutama natrium) di dalam daging ikan sehingga kadar abu juga meningkat.

\subsection{Kadar Protein}

Hasil analisa sidik ragam menunjukkan hasil bahwa $F$ hitung $<0,01$. Dapat disimpulkan bahwa perlakuan dari kelompok penggaraman dan perebusan memberikan pengaruh sangat nyata terhadap kandungan protein tepung teripang yang dihasilkan. Dengan demikian dilakukan uji lanjut. Hasilnya menunjukkan bahwa sampel dengan penggaraman $10 \%$, penggaraman $15 \%$, dan sampel penggaraman $20 \%$ berbeda nyata dengan 
sampel kontrol. Sedangkan sampel dengan kelompok perebusan perebusan 10 Menit, perebusan 20 menit dan perebusan 30 menit memiliki kadar protein yang sama dengan sampel kontrol.

Gambar 5. menunjukkan perlakuan lama perebusan yang semakin besar seiring lamanya waktu yang digunakan menyebabkan protein lebih lama terpapar pada kondisi panas dan menyebabkan kerusakan protein yang lebih besar. Sejalan dengan pernyataan (Lehninger, 2009). bahwa molekul protein bersifat amat rapuh dan segera rusak oleh panas. Selanjutnya, panas menyebabkan kerusakan protein dan terjadilah penurunan kadar protein.

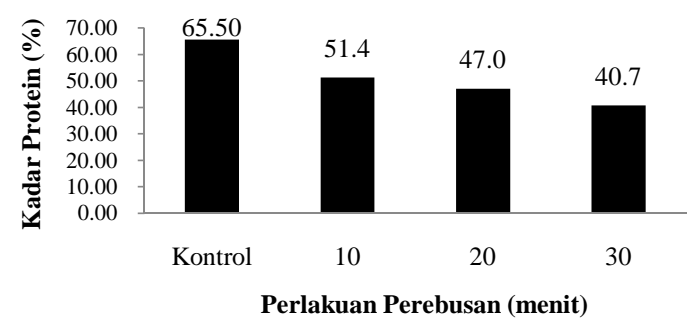

Gambar 5 Hubungan Lama Perebusan dengan Jumlah Kadar protein Tepung Teripang Perlakuan Perebusan

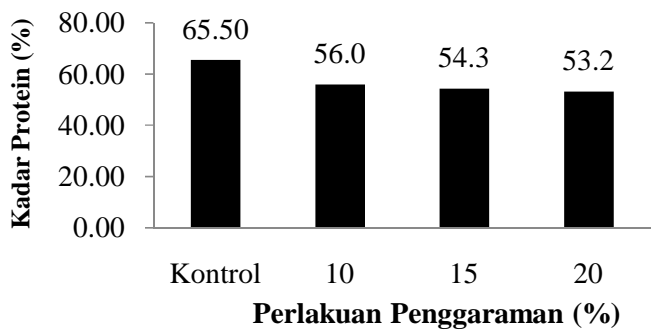

Gambar 6 Hubungan Konsentrasi Garam dengan Kadar protein Tepung Teripang Perlakuan Penggaraman.

Gambar 6 menunjukkan bahwa kadar protein mengalami penurunan seiring bertambahnya konsentrasi garam yang digunakan. Pada kondisi pemberian garam yang tinggi beberapa senyawa dapat mengalami perubahan baik secara fisik dan kimiawi, salah satu senyawa tersebut adalah protein. Kadar protein terendah yang didapatkan pada penggaraman dengan konsentrasi 20\% disebabkan karena semakin besar garam yang digunakan maka akan semakin besar pula protein yang mengalami kerusakan. Sejalan dengan penelitian tentang pengaruh penggaraman terhadap kadar protein ikan layang yang dilakukan oleh (Syahruddin, 2013) menunjukkan bahwa semakin kecil konsentrasi garam yang digunakan mengakibatkan semakin tinggi kadar protein yang kandung oleh ikan layang.

\subsection{Kadar Lemak}

Hasil analisa sidik ragam menunjukkan bahwa $\mathrm{F}$ hitung > 0,05. Berdasarkan data ini dapat disimpulkan tidak memiliki pengaruh nyata terhadap kandungan kadar lemak tepung teripang sehingga tidak dilakukan uji lanjut

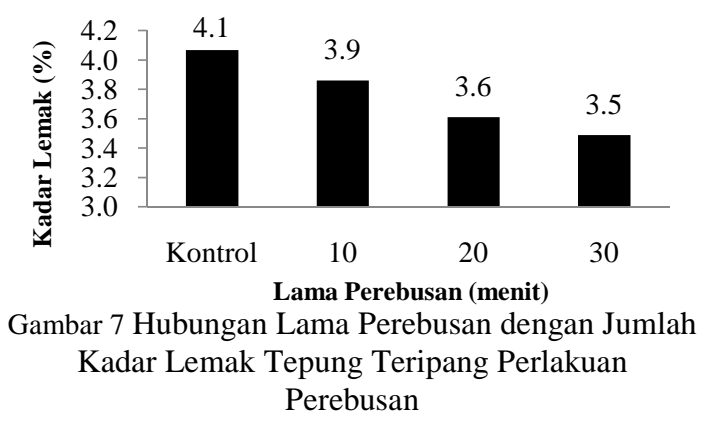

Gambar 7 menunjukkan bahwa tingkat kadar lemak pada sampel yang diberi perlakuan perebusan cenderung mengalami penurunan seiring lama perebusan yang dilakukan. Penurunan kadar lemak ini diduga karena semakin lama waktu perebusan maka akan semakin meningkat suhu yang diterima oleh bahan pangan. Suhu yang semakin tinggi mengakibatkan terjadinya kerusakan lemak yang semakin besar pula. pengaruh pemasakan terhadap komposisi zat bahan, bahwa nilai kadar lemak pada semua bahan pangan yang direbus mengalami penurunan, tingkat kerusakan lemak sangat bervariasi tergantung pada suhu yang digunakan dan lamanya waktu proses pengolahan. Makin tinggi suhu yang digunakan, maka semakin intens kerusakan lemak.

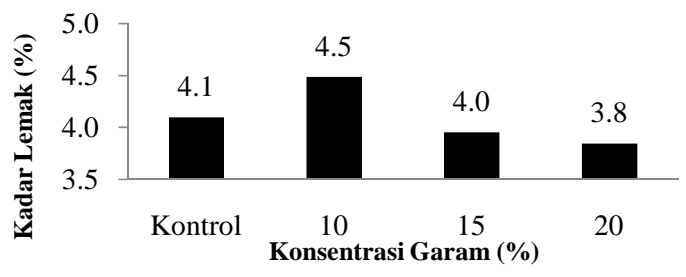


Gambar 8 Hubungan Konsentrasi Garam dengan

Kadar Lemak Tepung Teripang Perlakuan

Penggaraman.

Gambar 8 menunjukkan bahwa kadar lemak tepung teripang mengalami penurunan dengan meningkatnya konsentrasi garam. Menurut (Paparang, 2013) kadar lemak yang disebabkan oleh pengaruh konsentrasi garam terjadi karena garam dapat berperan sebagai katalis pada proses oksidasi dari lemak bahan pangan. Penurunan kadar lemak pada proses penggaraman juga diduga karena teripang pada umumnya mengandung lemak golongan asam lemak tak jenuh sehingga asam lemak jenuh tersebut cenderung mengalami penurunan akibat perlakuan penggaraman.

\subsection{Kadar Karbohidrat}

Hasil analisa sidik ragam menunjukkan bahwa $F$ hitung $>0,05$ sehingga tidak memiliki pengaruh nyata terhadap kandungan kadar karbohidrat tepung teripang yang dihasilkan, maka tidak dilakukan uji lanjut.

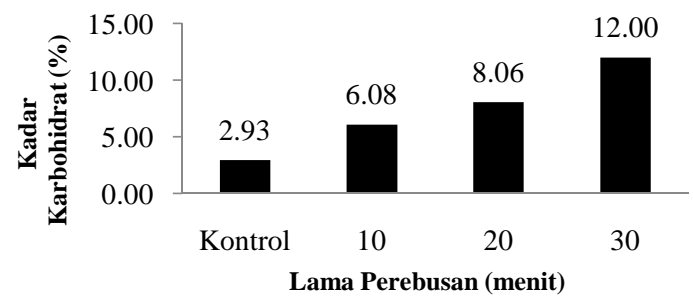

Gambar 9 Hubungan Lama Perebusan dengan Jumlah Kadarkarbohidrat Tepung Teripang Perlakuan Perebusan

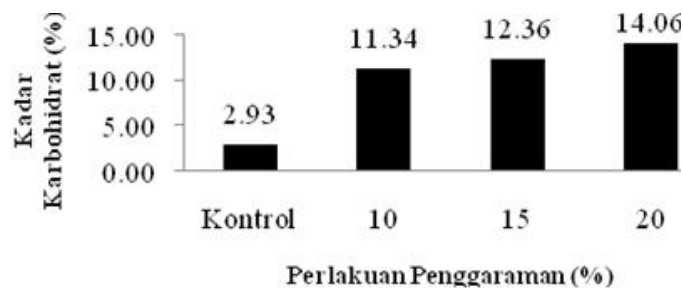

Gambar 10 Hubungan Konsentrasi Garam dengan Kadar karbohidrat Tepung Teripang Perlakuan Penggaraman

Gambar 9 dan Gambar 10 menunjukkan bahwa pada perlakuan perebusan kadar karbohidrat yang terkandung dalam tepung teripang mengalami peningkatan seiring dengan semakin lama waktu perebusan yang lakukan. Hal ini diduga karena pada perlakuan perebusan yang dilakukan menyebabkan beberapa komponen mengalami kerusakan dan ikut keluar bersama air, sehingga menyebabkan komponen yang banyak tersisa adalah karbohidrat. Perlakuan pemanasan yang dilakukan dengan suhu yang tidak terlalu tinggi menyebabkan kerusakan yang kurang berarti untuk komponen karbohidrat dalam pangan. Sejalan dengan penelitian (Setyohadi., Z. Lubis., 2014) menunjukkan semakin lama perebusan dan lama penyangraian maka kadar karbohidrat pada bahan pangan yang dihasilkan akan semakin meningkat. Peningkatan kadar karbohidrat dalam penelitian ini juga diduga disebabkan oleh pengaruh penurunan kadar air, kadar protein dan kadar lemak sehingga meningkatkan kadar karbohidrat yang dihasilkan tepung teripang. Hal ini sesuai dengan pernyataan (Winarno, 2004) yang menyatakan kadar karbohidrat ditentukan dengan menghitung selisih $100 \%$ dengan jumlah kadar protein, lemak, abu dan air, sehingga apabila jumlah kadar tersebut banyak yang menurun maka kadar karbohidratnya meningkat.

\subsection{Kadar $\mathrm{NaCl}$}

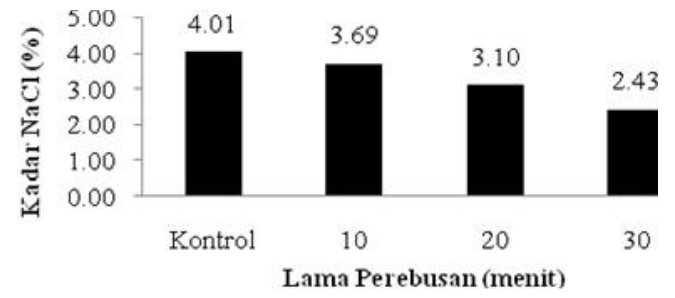

Gambar 11 Hubungan Lama Perebusan dengan Jumlah Kadar $\mathrm{NaCl}$ Tepung Teripang Perlakuan Perebusan

Gambar 11 memperlihatkan terjadi penurun kadar $\mathrm{NaCl}$ secara bertahap seiring lama perebusan. Pengurangan kadar garam diduga disebabkan oleh larutnya garam selama perebusan dan kelarutan semakin tinggi dengan semakin besar volume air dan semakin lama waktu perebusan. Menurut (Winarno, 2004), bahan pangan yang 
dimasak dengan menggunakan air akan meningkatkan daya kelarutan.

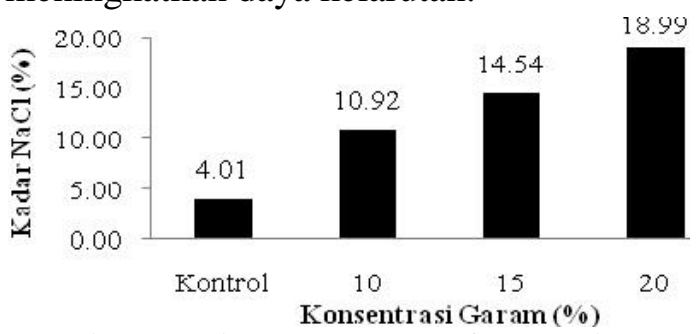

Gambar 12 Hubungan Konsentrasi Garam dengan

Kadar $\mathrm{NaCl}$ Tepung Teripang Perlakuan Penggaraman

Gambar 12 menunjukkan bahwa semakin besar konsentrasi $\mathrm{NaCl}$, jumlah $\mathrm{NaCl}$ didalam jaringan teripang juga semakin besar. Hal ini terjadi karena besarnya driving force penetrasi garam ke dalam teripang yang dipengaruhi oleh perbedaan konsentrasi $\mathrm{NaCl}$ awal dengan sel teripang. Ditegaskan dalam penelitian (Medina-Vivanco, Do Sobral, \& Hubinger, 2002), semakin besar perbedaan konsentrasi cairan antara sel ikan dengan $\mathrm{NaCl}$ mengakibatkan bertambah besarnya driving force.

\subsection{Warna}

Hasil analisa sidik ragam menunjukkan hasil bahwa $\mathrm{F}$ hitung $<0,01$ yang menyatakan sampel berpengaruh nyata sehingga dilakukan uji lanjut Duncan, menunjukkan bahwa sampel kontrol dan sampel dengan penggaraman 20\% menunjukkan berbeda nyata terhadap sampel dengan perebusan 10 menit, perebusan 20 menit sampel dengan perebusan 30 menit. Sedangkan sampel dengan penggaraman $10 \%$ dan sampel dengan penggaraman $15 \%$ memiliki berbeda nyata dengan sampel dengan perebusan 10 menit dan perebusan 20 menit.

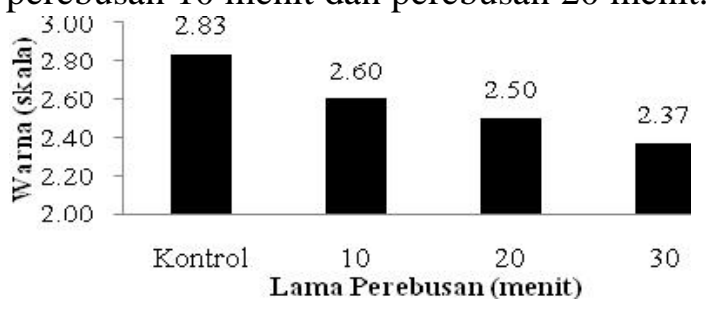

Gambar 13 Hubungan Lama Perebusan dengan Organoleptik Warna Tepung Teripang
Gambar 13 menunjukkan bahwa semakin lama pemanasan yang lakukan, penerimaan terhadap parameter warna tepung semakin rendah. Hal ini diduga karena adanya kandungan karbohidrat yang ada pada teripang sehingga pada saat terjadi pemanasan karbohidrat tersebut mengalami karamelisasi sehingga tepung berwarna coklat. Sesuai dengan pernyataan (Winarno, 2004) menyatakan bahwa dalam pengolahan yang melibatkan pemanasan, karbohidrat akan mengalami karamelisasi (pencoklatan non-enzimatis). Pencoklatan juga diduga akibat perubahan pada protein saat pemanasan.

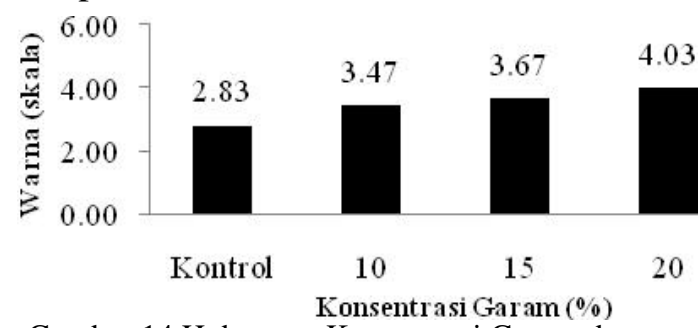

Gambar 14 Hubungan Konsentrasi Garam dengan

Organoleptik Warna Tepung Teripang

Gambar 14 menunjukkan semakin tinggi konsentrasi garam maka semakin tinggi kencenderungan panelis untuk menyukai produk tepung teripang. Tepung teripang yang dihasilkan pada proses perlakuan garam memberikan warna yang cenderung putih. Hal ini disebabkan oleh adanya kristal garam yang terkandung pada tepung teripang. Sesuai dengan penelitian yang dilakukan oleh (Rinto., Arafah., \& Utama, 2009) yang menyatakan bahwa tingginya konsentrasi garam pada pengolahan ikan asin dan dilakukannya penggaraman berulang akan menyebabkan ikan asin menjadi lebih putih karena adanya kristal garam.

\subsection{Aroma}

Hasil analisa sidik ragam bahwa $F$ hitung $<0,01$ yang menujukkan sampel berpengaruh sangat nyata terhadap sehingga dilakukan uji lanjut Duncan. Hasilnya menunjukkan bahwa tepung teripang perebusan 30 menit, perebusan 20 menit dan perebusan 10 menit menunjukkan berbeda nyata terhadap 
sampel penggaraman $20 \%$, dan berbeda nyata terhadap sampel penggaraman $15 \%$ dan penggaraman $10 \%$. Sedangkan sampel perebusan 10 menit dan sampel kontrol menunjukkan berbeda nyata dengan sampel penggaraman $20 \%$.

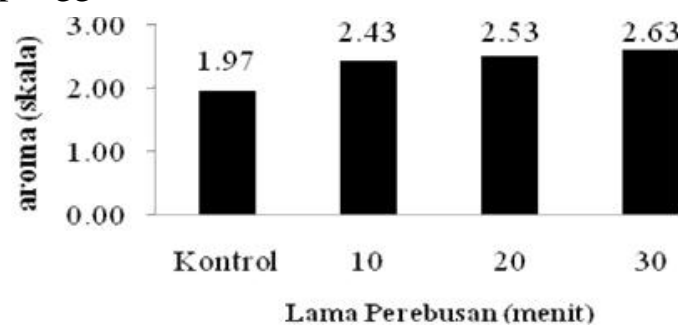

Gambar 15 Histogaram Hubungan Lama Perebusan dengan Organoleptik Aroma Tepung Teripang

Gambar 15 menunjukkan, semakin lama waktu pemanasan yang dilakukan maka penerimaan panelis terhadap parameter aroma semakin meningkat. Hal ini diduga karena semakin lama waktu perebusan yang dilakukan maka suhu akan semakin meningkat sehingga membuat proses oksidasi semakin lambat atau terhambat disebabkan oleh semakin banyaknya enzim perombak lemak yang rusak (Winarno, 2004) menyatakan bahwa perubahan atau penguraian lemak dapat mempengaruhi bau dan rasa suatu bahan makanan sehingga kerusakan lemak dapat menurunkan nilai gizi serta menyebabkan penyimpangan bau dan rasa.

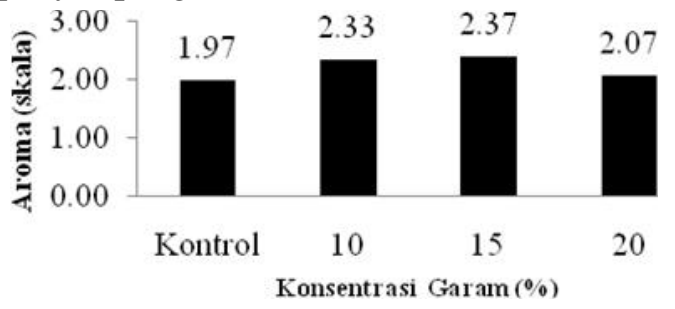

Gambar 16 Hubungan Konsentrasi Garam dengan Organoleptik Aroma Tepung Teripang

Berdasarkan data yang ditampilkan pada Gambar 16 terjadi peningkatan kesukaan terhadap parameter aroma dari sampel kontrol menuju sampel penggaraman $15 \%$, dan kembali menurun pada penggaraman 20\%. Namun nilai rata-rata dari parameter aroma pada kelompok penggaraman memiliki nilai 2,18 (Lampiran 8c). Hal ini menunjukkan bahwa nilai rata-rata kesukaan terhadap parameter aroma berada pada tingkat Tidak Suka. Pada proses penggaraman bahan pangan pada dasarnya tidak memberi pengaruh terhadap kondisi aroma suatu bahan. Bahkan garam cenderung memiliki fungsi mempertahankan aroma alami dari bahan pangan. bahwa kelebihan proses dehidrasi osmosis dibanding metode pengeringan konvensional antara lain dapat mempertahankan karakteristik awal makanan (warna, aroma, nutrisi, dan tekstur makanan), tidak terjadi enzymatic browning dan tidak melibatkan perubahan fasa selama pengeringan.

\subsection{Tekstur}

Hasil analisa sidik ragam menunjukkan bahwa $\mathrm{F}$ hitung > 0,05 yang menyatakan tidak berpengaruh nyata sehingga tidak dilakukan uji lanjut.

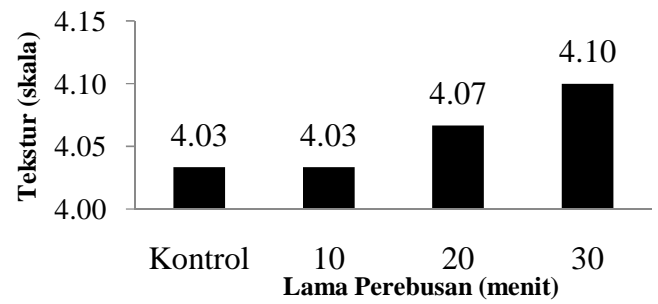

Gambar 17 Histogram Hubungan Lama Perebusan dengan Organoleptik tekstur Tepung Teripang

Gambar 17 menunjukkan bahwa kecenderungan panelis menyukai tepung teripang semakin meningkat pada sampel dengan perlakuan perebusan. Hal ini disebabkan karena pada perlakuan perebusan yang dilakukan menyebabkan daging menjadi lebih lembut dan tampak kompak. Menurut (Irawan, 1997) tujuan pemasakan baik perebusan maupun pengukusan pada daging dilakukan untuk mengurangi kadar air dan mempertahankan mutu bahan yaitu tekstur yang padat dan kompak.

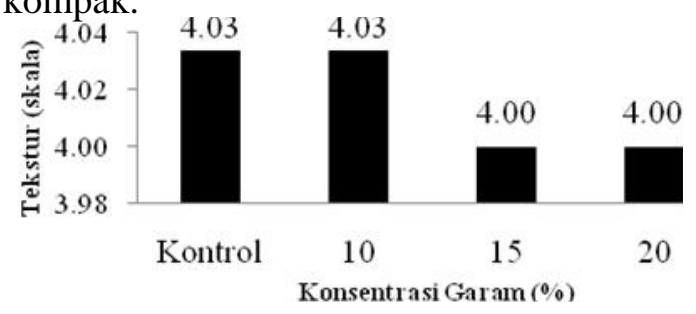


Gambar 18 Histogram Hubungan Konsentrasi Garam dengan Organoleptik Aroma Tepung Teripang

Gambar 18 menunjukkan kecenderungan sensorik tekstur mengalami penurunan seiring dengan bertambah konsentrasi garam yang di berikan. Hal ini diduga karena adanya kristal garam yang membuat tekstur pada sampel kelompok penggaraman lebih keras dan tidak kompak dibandingkan dengan sampel yang mengalami proses perebusan. Sesuai dengan penelitian yang dilakukan oleh (Fatmawati \& Mardiana, 2014) dalam pembuatan tepung ikan yang menunjukkan hasil bahwa tepung ikan yang diolah dengan cara perebusan memiliki skor tinggi atau disukai oleh panelis karena pada tahap perebusan daging ikan menjadi lebih lembut jika dibandingkan dengan tanpa perebusan. Perebusan pada pembuatan teripang kering dimaksudkan untuk memantapkan sehingga semua teripang menjadi kenyal teksturnya (Suryaningrum. \& Dwi., 2008).

\section{KESIMPULAN}

1. Pengaruh perlakuan perebusan 10 menit, 20 menit dan 30 menit serta penggaraman dengan konsentrasi $10 \%$, $15 \%$ dan $20 \%$ dalam pembuatan tepung teripang tidak mempengaruhi secara nyata kandungan nutrisi dan organoleptik tepung teripang.

2. Perlakuan perebusan menghasilkan produk tepung teripang yang rendah daya terimanya dari segi warna oleh konsumen. Namun dari segi tekstur dan aroma konsumen cenderung lebih menyukai tepung teripang yang melalui proses perebusan. Pada perlakuan penggaraman panelis lebih cenderung menyukai dari segi warnanya karena menghasilkan tepung teripang yang lebih putih.

3. Pembuatan tepung teripang baik dengan perlakuan perebusan ataupun penggaraman masih tergolong memiliki kandungan nutrisi yang cukup tinggi. Sehingga sangat berpotensial untuk dikembangkan lebih luas lagi pada produk pangan kaya nutrisi.

\section{DAFTAR PUSTAKA}

Apriantono. (2002). Pengaruh Pengolahan Terhadap Nilai Gizi dan Keamanan Pangan. Makalah Seminar Kharisma Online.

Fatmawati, \& Mardiana. (2014). Tepung Ikan Gabus Sebagai Sumber Protein (Food Supplement). Jurnal Bionature.

Harmayani, Utami., T., \& Khairina, R. (2000). Pemanfaatan Asap Cair Pada Pengolahan "Wadi" Ikan Betok (Anabas testudineus Bloch ) Makanan Hasil Fermentasi. Jurnal Makanan Tradisional Indonesia, 2(3), 1-10.

Irawan, A. (1997). Pengawetan Ikan Hasil Perikanan. Solo: CV. Aneka.

Lehninger. (2009). Dasar-dasar Biokimia Jilid I. Jakarta: Erlangga.

Medina-Vivanco, M., Do Sobral, P. J. A., \& Hubinger, M. D. (2002). Osmotic dehydration of tilapia fillets in limited volume of ternary solutions. Chemical Engineering Journal. https://doi.org/10.1016/S13858947(01)00290-X

Paparang, R. W. (2013). Studi pengaruh variasi konsentrasi garam terhadap citarasa peda Ikan Layang (Decapterus russelli). Jurnal Media Teknologi Hasil Perikanan.

Rinto., E., Arafah., \& Utama, S. . (2009). Kajian keamanan pangan (formalin, garam dan mikrobia) pada ikan sepat asin produksi Indralaya. Jurnal Pembangunan Manusia, 8(2).

Rochima. (2005). Dinamika Jumlah Bakteri selama Fermentasi selama Processing Ikan Asin Jambal Roti. Universitas Padjadjaran, Bandung.

Setyohadi., Z. Lubis., Y. . P. (2014). Pengaruh Lama Perebusan dan Lama Penyangraian Dengan Kuali Tanah Liat Terhadap Mutu Keripik Biji Durian (Durio zibethinus Murr). Rekayasa Pangan Dan Pert, 2(3).

Suryaningrum., \& Dwi., T. (2008). 
Teripang: Potensinya Sebagai Bahan Nutraceutical dan Teknologi Pengolahannya. Squalen, 3(2).

Syahruddin. (2013). Pengaruh Penggaraman Terhadap Protein Ikan Layang (Decapterus Ruceli. Jurnal Pengolahan Hasil Perikanan (JPHI).

Winarno. (2004). Kimia Pangan dan Gizi. Jakarta: gramedia Pustaka Utama. 